\title{
sine
}

Volume and Issues Obtainable at Center for Sustainability Research and

Consultancywww.globalcsrc.org

Journal of Business and Social Review in Emerging Economies

ISSN: 2519-089X; (Online) 2519-0326

Volume 2: Issue 1 June 2016

\section{Sustainable Service Quality of Water and Sewerage Companies}

\author{
${ }^{1 *}$ AbrariSalleh, ${ }^{2}$ Sha'ri Mohd Yusof \\ ${ }^{1}$ PhD Candidate, UTM Razak School of Engineering and Advanced Technology, UniversitiTeknologi Malaysia, \\ irarba69@yahoo.com \\ ${ }^{2}$ Professor, UTM Razak School of Engineering and Advanced Technology, UniversitiTeknologi Malaysia, \\ shari@utm.my
}

\begin{tabular}{l}
\hline ARTICLEDETAILS \\
\hline History \\
Revised Format: May 2016 \\
AvailableOnline: June 2016 \\
\\
\hline Keywords \\
Service Quality \\
Sustainability \\
Water and Sewerage Industry \\
Regulatory
\end{tabular}

JEL Classification:

$Q 56, Q 59, P 23, P 29$

\begin{abstract}
Objective: The purpose of this conceptual paper is to critically review and discuss the perceived service quality of the water and sewerage services with the addition of sustainability factor with respect to economic, environmental and social aspects among the Malaysian water and sewerage companies.

Methodology:The review of various service quality models and sustainability models that has led to our findings on knowledge gap between sustainability and service quality especially in utility services sector (water and energy).

Results: The authors propose a modified SERVQUAL model with six independent variables namely tangibles, reliability, responsiveness, assurance, and empathy with an additional dimension i.e. sustainability. Addition of sustainability has modified the existing SERVQUAL instrument to be called sustainable service quality or SUSSERV.

Implication: The paper involves discovering the lack of research in sustainability service quality particularly in the context of Malaysian water services (including sewerage). This review should be able to answer the question why SERVQUAL is not appropriate for measuring water services quality thus requiring some improvement or modification using SUSSERV.Previous efforts and focus have been made based on water quality and water treatment or process quality (technical issues), thus this paper is an attempt to fill the gap between service, product and process quality by adding sustainability dimension in service quality evaluation.
\end{abstract}

(C) 2016 The authors, under a Creative Commons AttributionNonCommercial 4.0

\section{Introduction}

The water services (water and sewerage) have been in our country for many years where the industry players have spent great amount of resources, effort and attention on infrastructure and water quality but

*Corresponding author's email address: irarba69@yahoo.com

Citation: Salleh, A. and Yusof, S. M. (2016). Sustainable Service Quality of Water and Sewerage Companies. Journal of

Business and Social Review in Emerging Economies,2 (1) 1-12. DOI: https://doi.org/10.26710/jbsee.v2i1.13 
not much on the quality of services itself. Service quality relates to how customers perceive the actual service performance against their expectation (Parasuraman, 1985). National Water Services Commission is a regulatory body for the water supply and sewerage services in Peninsular Malaysia, Putrajaya and Labuan. It is important to understand and identify imperative issues relating to service quality and their relationship with sustainability as both will normally describe the growing concern of the companies and to ensure being well accepted by their customers although water quality and water insecurity are the main factor for sustainable development (Habiba et.al., 2014).

\subsection{The Importance of Research on Sustainable Service Quality of Malaysian Water Industry}

While sustainability is an important aim for many companies, there is a question why and how the service quality measuring instrument needs to be changed. Therefore, this research should be able to answer the question why the existing SERVQUAL is not suitable for measuring service quality of water services thus requiring some improvement or modification. This research will explore and explain the impact of Malaysian water and sewerage operators' service quality towards sustainability and will allow for further future improvements because this study is new in Malaysia. The main objectives of this research are to determine the perceived service quality of the water and sewerage operatorsand also to determine the relationship between sustainability and service quality factors by using an instrument for sustainable service quality or SUSSERV that has been developed to measure service quality in water and sewerage services. The findings can be used as a reference for SPAN and government agencies to evaluate or analyse the performance of water and sewerage operators and to the body of knowledge. Furthermore, there is a lack of research for quality in water and sewerage services especially in Malaysia.

\section{Literature review}

\subsection{Conceptual Definitions}

Gronroos (1978) started the idea of service-oriented approach then subsequently Gronroos (1982) developed a new model for service quality. The model has been further improved and a new model has been developed by Gronroos (1984) namely Service Quality Model which has specifically mentioned the concept of perceived and expected services. Subsequently, Parasuraman et. al. (1985, 1988), extended Service Quality Model and developed the SERVQUAL model for the same purposes as Gronroos (1984) which is to determine the perceived quality level. The important conceptual definitions used for the purpose of this research mainly involve the SERVQUAL or service quality model that was developed by Parasuraman et. al. (1985, 1988). The main components of high quality service or ten dimensions (10Ds) of service quality were collapsed into five dimensions (5Ds) factors is explained in Figure 1. This model employs a survey in the form of a questionnaire that can be used to measure customers' expectations of service quality in terms of these five dimensions, and their perceptions of the service they received. Enquist et.al. (2007) investigated the relationship between service quality and sustainability using own developed model named Values-Based Service Quality for Sustainable Service Business comprised four dimensions namely technical, functional, experiential and human resources/ corporate climate against five sustainability dimensions namely ethical, social, "nature-philosophic", economic and legal. The concept of sustainability was briefly discussed through areview of supply chain management literature by Carter and Rogers (2008) that suggested a sustainable supply chain management model with three important factors namely social, environmental, and economic. The factors are supported by four features of sustainability - risk management, transparency, strategy, and culture. The peak of economic performance will occur at the intersection of environmental, social, and economic. Companies that are able to maximize the performance of the three dimensions of the triple 
bottom line simultaneously will achieve sustainability better than companies that only try to maximize the performance of one or two, whether economic, social and environmental (Carter and Rogers, 2008) as shown in Figure 2.

Figure 1 : SERVQUAL Factors or Dimensions

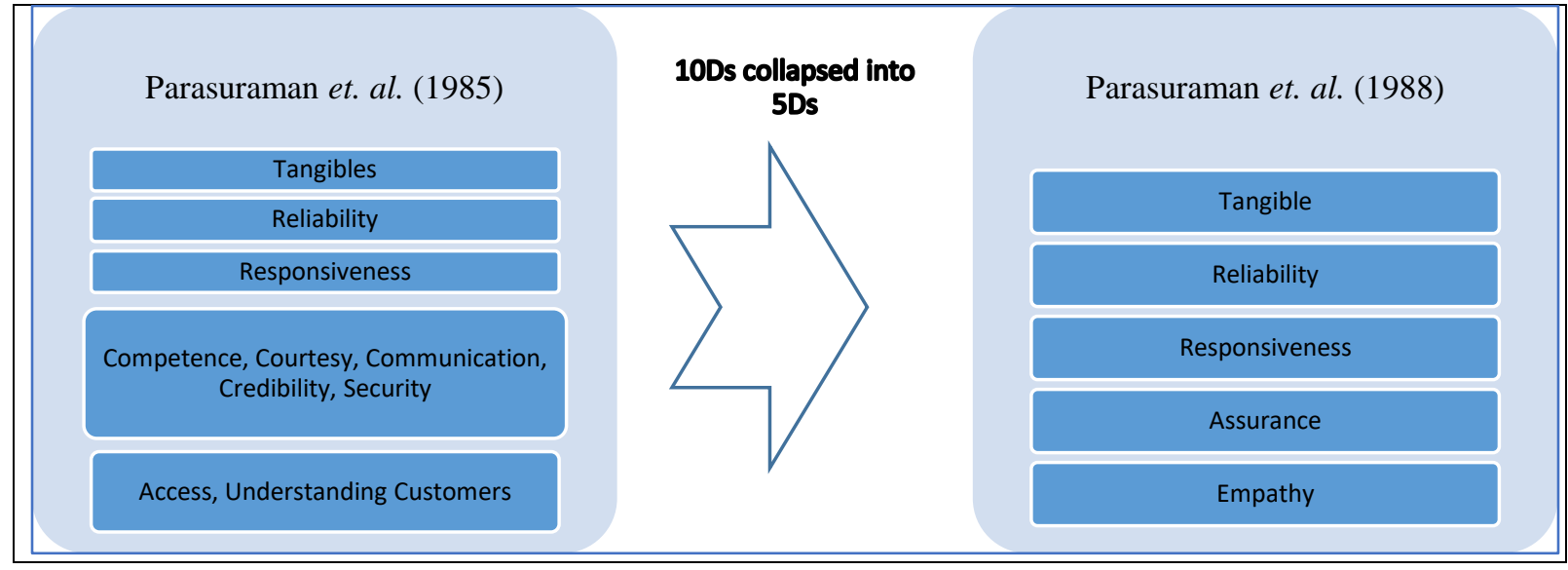

Source: Adaptation from Parasuraman et. al. $(1985,1988)$

Figure 2 : Sustainable Supply Chain Management Model

Source: Carter and Rogers (2008)

SUSSERV consists of six independent variables on service quality namely tangibles, reliability, responsiveness, assurance, empathy and sustainability. The first five independent variables are based on Parasuraman (1988) SERVQUAL. Meanwhile, the sustainability variable which comprises economy, environment and social factors are based on Carter and Rogers (2008). These variables will be used for the purpose of identifying service quality status of any company. Service quality is related to the profitability of a company. Any profitability to any company will definitely impact the economy. The authors are of the opinion that, the Five Rules of Services elements by Gronroos (1988) are comparable with Sustainable Factors by Carter and Rogers (2008) as shown in Figure 3.

Figure 3 : Five Rules of Service Comparable with Sustainable Factors

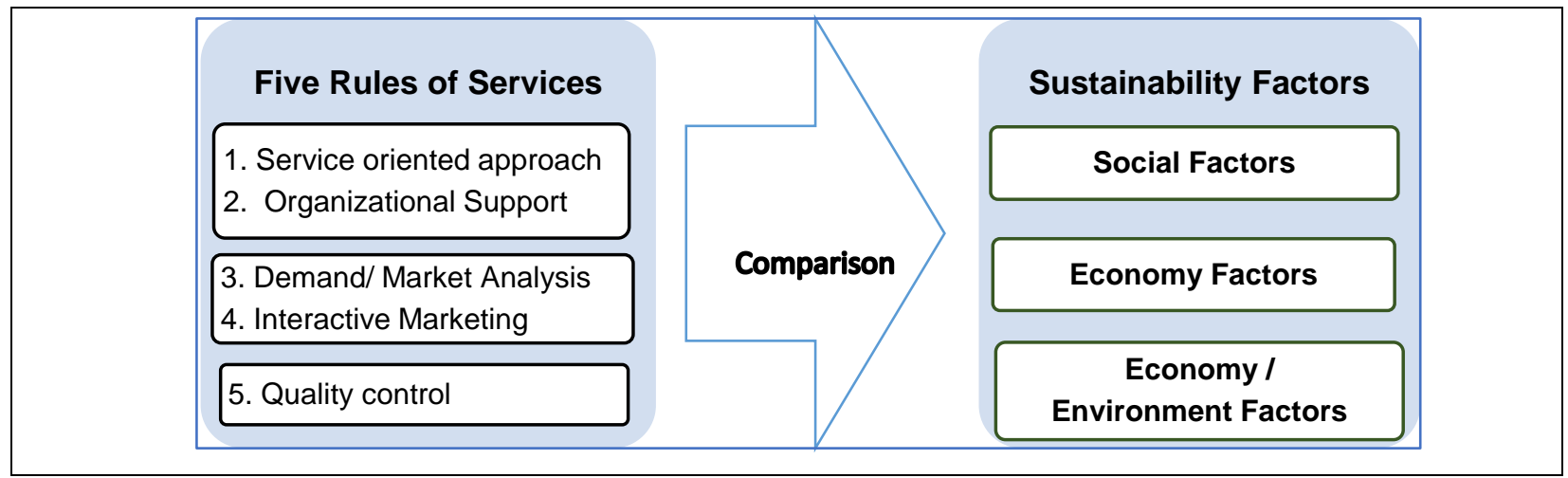

Source: Adaptation from Gronroos (1988); Carter and Rogers (2008) 


\subsection{Services and Quality}

Parasuraman et.al. (1985) have summarised the definition of services from previous authors as having three characteristics namely Intangibility (viewed as performances rather than objects), Heterogeneity (services performance often varies from different producer and customer) and Inseparability. Inseparable consistent with the definition of services that involves the interaction between the producer and the consumer. The consumers or purchasers themselves can assess the quality of service provided (Naik et. al., 2010). Furthermore, Parasuraman (1998) defined "service" and "services" are not entirely synonymous although both share common traits such as intangibility and perishability. Services are "intangible products" that a supplier markets to its consumers. Gronroos (2008) identified service in three different aspects; (1) as an activity; (2) on the customer's value creation; and (3) on the provider's activities.

It is difficult to determine customers' expectation and whether they are satisfied with the company, its products, and its service. Numerous definitions of quality have been given by researchers, practitioners and gurus from many perspectives. According to Garvin (1984), the definition of quality can be identified using five major approaches: (1) Transcendent - Quality is synonymous with "innate excellence"; (2) Product based - Quality is viewed as a precise and measurable variable; (3) User based - Quality is associated with customers' personal view of quality and satisfaction; (4) Manufacturing based - Quality is identified as "conformance to requirements"; and (5) Value based -in terms of costs and prices. Product based and user based approaches are normally viewed by marketing people. Conversely, most engineers viewed quality as manufacturing-based. With a multiple perspectives in viewing quality, companies can take advantage by shifting perspectives on quality as a product move from design to market. In other words, quality is when a product is cheap and easy to produce and market and at the same time makes the consumer trust and feel satisfied with the product or service.

\subsection{Type of Quality - Product, Process and Services}

Basically there are three types of quality that are often discussed by many scholars namely Products quality(Yusof and Aspinwall, 2001), Processes quality (Agus and Hajinoor, 2012) and Services quality (Parasuraman et. al., 1985, 1988; Parasuraman, 1998, 2004, 2010; Gronroos, 1978, 1982, 1984, 1998, 2001). The element of quality was discussed by Gronroos (1984) from the Service Quality model on three types of qualities comprised of perceived service quality, technical quality (what?) and functional quality (how?). Kang and James (2004) clarified that the "perceived service quality model" replaces the product attributes of a physical product in the consumption of services. The customers perceived what they received as the outcome of the process in which the resources are used, i.e. the technical or outcome quality of the process. Functional quality is also a part of the process quality dimension. The differentiation between technical quality and functional quality can be seen in the hospital and healthcare services (Abuosi and Atinga, 2013) and also in higher learning institution (Kong and Muthusamy, 2011). This is because their services involve high technology tools, equipment and peripherals which are related to functional quality. For manufacturing with total quality management (TQM) practices, other than service quality, process and product quality are being considered as well as technical quality because there is a positive relationship between TQM practices and market orientation (Lam et. al., 2012).

Figure 4 : Type of Quality from Different Perspectives 


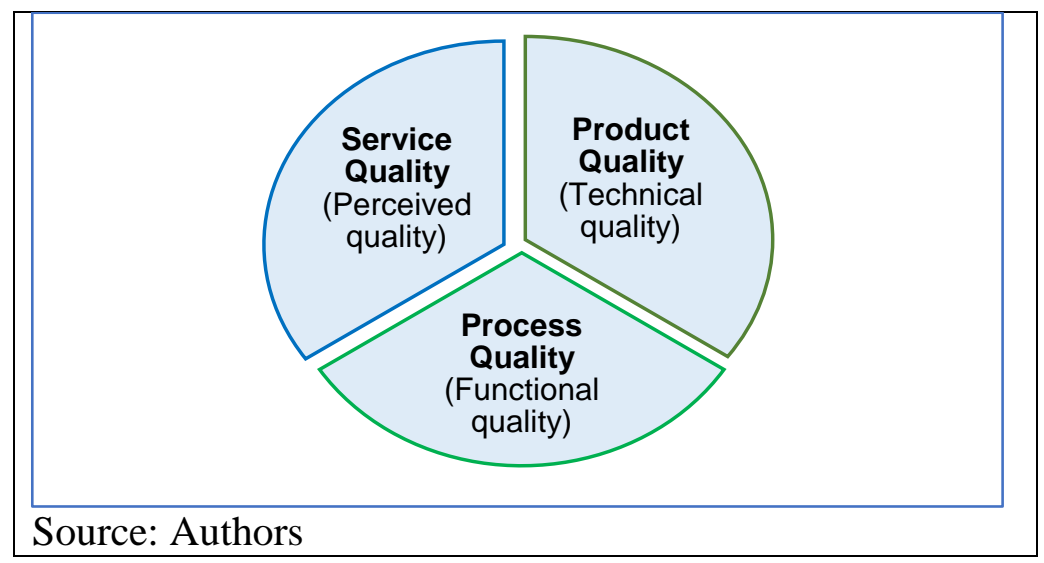

With reference to Gronroos' (1984) Service Quality Model, the authors are of the opinion that quality can also be seen from a different perspective and comparable to the same type of quality to be discussed in this chapter namely product quality, process quality and service quality as illustrated in Figure 4. Although Gronroos (1978), (1982), (1984) and (2001) has discussed and emphasized the significance of corporate image in the research topic of service quality, the authors are of the opinion that corporate image is not applicable holistically to any company, business entity and individual based on the following arguments; (1) Something that one have to build over time but definitely not overnight or long-term process (Fattet. al., 2000) ; (2) Only big corporation have corporate image due to the high cost to build and maintain good image and involves the effort of the entire company (Fattet. al., 2000); (3) Not exclusively and ultimately owned because the real owner is the general public. Although corporate image is an intangible item it must be generally accepted by surrounding community because and it is the external publics' perceptions that result from their interactions with the organization (Abratt and Mofokeng, 2001). Product quality is a very important aspect in Malaysian manufacturing (Yusof and Aspinwall, 2001). Process and product quality are interrelated in manufacturing whereby process quality have a direct relationship toward product quality performance and business performance (Agus and Hajinoor, 2012).

\subsection{The Review of Service Quality (SERVQUAL) Model}

The concept of service quality by Gronroos (1982) argued about non-segregation between services as objects of marketing and services as marketing variables. Subsequently, Parasuraman et. al. (1985) has confirmed that service quality is more difficult to be evaluated based on the same reasoning. Prior to that, the topic of service quality was being mentioned by Gronroos (1978) and later being discussed by Gronroos (1982) with a new model of service quality that has been developed accordingly. The ideas brainstormed by him earlier has resulted to the second model developed by Gronroos (1984) called Service Quality Model. The most important concept is managing the perceived service quality by managing the gap between perceived services and expected services. It has been thus concluded that technical quality is more important than the functional quality. A such, treated water produced by the water operators is a good example of technical quality or a technical outcome of the process. However, the customers are also interested to know water treatment process itself; curious about technology, tools or equipment used and how technical quality is obtained. It is important to them and to their view of the service they have received and this is called functional quality. Functional dimensional is perceived in a subjective manner, therefore the functional quality can not be evaluated impartially compared to the technical quality. However, service quality was discussed and further refined by Parasuraman et. al. (1985, 1988), thus the SERVQUAL model has been developed. Parasuraman et. al. (1985) revealed that ten dimensions (namely tangibles, reliability, responsiveness, communication, credibility, security, 
competence, courtesy, understanding, access) that consumers use in forming expectations about and perceptions of services, are dimensions that transcend different types of services. They developed 97 items representing ten dimensions of service quality identified using seven points Likert scale ranging from 7 (strongly agree) to 1 (strongly disagree). The research also mentioned four key discrepancies or gap 1 to 4 on the service provider's side that are likely to affect service quality as perceived by consumers (gap 5). Subsequently, Parasuraman et. al. (1988), further refined and condensed the instrument from 97 items to 22 item to assess customers' perceptions of service quality in service and retailing industry. They have maintained five most important dimensions in Service Quality model namely Tangibles, Reliability, Responsiveness, Assurance and Empathy.

\subsection{Modified Service Quality (SERVQUAL) Model}

Although SERVQUAL model is proven to be a reliable and valid tool to measure service quality, it has not stopped the researchers from enhancing or extending its capability through some modifications to suit their objectives and the areas of research or industry. Some modified SERVQUAL models that has been developed include SERVPERF, PAKSERV, FM-SERVQUAL, BSQ Index and SSQ. The analysis on the modified SERVQUAL models used by scholars in previous research have been summarised as shown in Table 1 and brief explanations on the models are; (1) SERVPERF model measures service quality and performance or comparison of performance perceptions with expectation. Both service quality and satisfaction effected purchase intentions but satisfaction has a stronger and more consistent effect proving that SERVQUAL model has some limitation (Tayloret. al., 1993). Despite critic on SERVQUAL model, Cronin (2003) still cannot totally confirm that there is a direct correlation or linear relationship between service quality and customer satisfaction, but at the same time would be misleading to suggest that they are totally unrelated; (2) Pakistan Service Quality or PAKSERV model scale used to measure the service quality in the Pakistan context provides an Asian cultural perspective as compared to western cultural model; (3) Facility management service quality or FM-SERVQUAL model has proven to be a reliable instrument that contributes to the quality improvement of the delivery system in Malaysian Local Authorities; (4) Bank Service Quality (BSQ) Index model revealed that reliable communication and responsiveness have a direct bearing on perceptions of quality; (5) Sports service quality or SSQ model is used to investigate the relationship between emotional experience (EE) and user satisfaction (US) for sports competitions or training venues. Other researchers used the existing SERVQUAL model by Parasuraman et. al (1985 and 1988) and modified the instrument to suit their research in the areas of study such as hospital and healthcare (Kilbourne et. al., 2004; Abuosi and Atinga, 2013); banking (Amin and Isa, 2008; Kumar et. al., 2009; AmatTaapet. al., 2011); manufacturing with TQM practices (Lam et.al., 2012).

Table 1 : Summary of Modified SERVQUAL Models

\begin{tabular}{|c|c|c|c|c|c|c|}
\hline & \multirow[b]{2}{*}{$\begin{array}{c}\text { Scholars } \\
\text { (Developed Modified SERVQUAL } \\
\text { Models) }\end{array}$} & \multicolumn{5}{|c|}{ Service Quality Dimensions (Ds) } \\
\hline & & 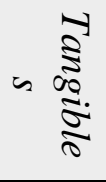 & $\begin{array}{r}\frac{5}{5} \\
\frac{5}{5} \\
\frac{5}{5} \\
5\end{array}$ & 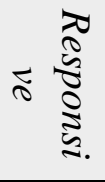 & $2 \underset{\substack{\vdots \\
\vdots}}{\stackrel{\Delta}{\vdots}}$ & 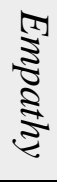 \\
\hline \multirow[t]{2}{*}{1.} & Cronin and Taylor, 1992 [SERVPERF] & $\sqrt{ }$ & $\sqrt{ }$ & $\sqrt{ }$ & $\sqrt{ }$ & $\sqrt{ }$ \\
\hline & Others $(D s)$ & \multicolumn{5}{|l|}{ None } \\
\hline \multirow[t]{2}{*}{2.} & Raajpoot, 2004 [PAKSERV] & $\sqrt{ }$ & $\sqrt{ }$ & - & $\sqrt{ }$ & - \\
\hline & Others (Ds) & \multicolumn{5}{|c|}{ sincerity, personalisation and formality } \\
\hline 3. & $\begin{array}{l}\text { Wan Yusoff et. al., } 2008 \text { [FM- } \\
\text { SERVQUAL] }\end{array}$ & $\sqrt{1}$ & $\sqrt{ }$ & $\sqrt{ }$ & $\sqrt{ }$ & $\sqrt{ }$ \\
\hline
\end{tabular}




\begin{tabular}{|c|c|c|c|c|c|c|}
\hline & \multirow[b]{2}{*}{$\begin{array}{c}\text { Scholars } \\
\text { (Developed Modified SERVQUAL } \\
\text { Models) }\end{array}$} & \multicolumn{5}{|c|}{ Service Quality Dimensions (Ds) } \\
\hline & & 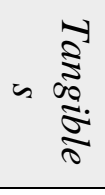 & 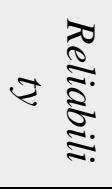 & 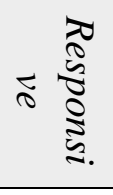 & $2 \underset{\vdots}{\vdots}$ & 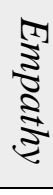 \\
\hline & Others $(D s)$ & \multicolumn{5}{|c|}{ Professionalism } \\
\hline \multirow[t]{2}{*}{4.} & Abdullah et. al.,2011 [BSQ Index] & - & $\sqrt{ }$ & $\sqrt{ }$ & - & - \\
\hline & Others (Ds) & \multicolumn{5}{|c|}{$\begin{array}{l}\text { Systemization of service and Reliable } \\
\text { Communication }\end{array}$} \\
\hline \multirow[t]{2}{*}{5.} & Voon et. al., 2014 [SSQ] & - & $\sqrt{ }$ & $\sqrt{ }$ & - & - \\
\hline & Others $(D s)$ & \multicolumn{5}{|c|}{ Peripheral, core and value } \\
\hline
\end{tabular}

Source: Authors

\section{Sustainability}

To date, there is steady increase in research in the area of sustainability conducted by many scholars and researchers across the field of knowledge such as social sciences (Enquistet. al., 2007; Carter and Roger, 2008; Amranet. al. 2010), and engineering (Hosseinpouret. al., 2015; Ali et. al. 2013). Sustainable development is a major challenge and proves to be a daunting task to understand the inter-related complex issues. To date, sustainable development is an important concern, probably the most important, for business and society, and even for those who for years argued in favour of the importance of change towards sustainable development, this issue is now perceived as being more apparent and urgent. Therefore, sustainability is a key issue for the business community and crisis resulting from rapid industrialisation has caused a significant social and environmental side effects (Amranet. al. 2010). The policy maker especially in water and sewerage industry will always want its industry to be sustainable and relevant to the consumers' needs. Change will definitely involve many parties and strong political will and support should be present to achieve its objectives.

\subsection{Type of Sustainability - Product, Process and Services}

For the purposes of this research, other than product and process, sustainability of services will also be discussed in detail by the authors based on past research, empirical findings and scientific references. Companies increases products marketing aggressively for profit has led to a new products cycle shorter. Business success will be achieved by companies which can respond quickly to new market changes and customer needs. They will always look for solutions and improvements or sustainability in products and processes. Gaining product sustainability is important but a difficult practice in business organizations (Ali et. al., 2013). Therefore, meeting functional requirements and sustainability is critical for product success in the current market. Products compete on the basis of not only price, functions and diversity, but also sustainability. Sustainable product or system is its ability to work continuously during its life cycle with less impact to the environment (Hosseinpouret. al., 2015). Sustainability does have an impact to the implementation of services and indirectly attributes to the quality of services. Social and economy factors are among the many attributes that are correlated with service quality.

\subsection{Sustainability Components - Environment, Society and Economy}

Sustainability that has been discussed by social science scholars basically consists of three components (Enquistet. al., 2007; Carter and Rogers, 2008; Kheong, 2008; Lepage, 2009; Sloan, 2010; Fernando, 2012) namely Economy, Environment and Society. However, Lehtinen(2012) briefly reviewed and 
suggested four criteria needed to be considered to evaluate sustainability which are Environmental, Social, Economic, and Relationship (transparency, risk management, partnerships) factors. It can be summarized from these two sets of criteria that Environmental factor has a major impact towards sustainability. Sustainability in manufacturing may differ from service industry especially with the existence of social factor, thus can be further researched to service industries. Joseph (2013) concluded that only staff directly involved in the sustainable development activity implementation understood the meaning of the sustainable development concept.The report on economic aspect should cover the various financial aspects of the water service operations (Kheong, 2008). There is an element of cost and benefit or profit and loss for the purpose of measuring sustainability such as cost-efficient model (Benedetti et. al., 2012). From the above discussions, it can be concluded that sustainability has a positive relationship towards profitability, cost reduction, economic performance (growth) and competitive advantage (Amranet. al., 2010 and Carter and Rogers, 2008).

\section{Conceptual Model}

Table 2 : Summary of Authors and SUSSERV Dimensions

\begin{tabular}{|c|c|}
\hline Dimensions & Authors \\
\hline Tangibles & $\begin{array}{l}\text { Parasuraman et.al. (1985, 1988); Cronin and Taylor (1992); Kilbourne et. } \\
\text { al. (2004); Aguset. al. (2007); Amin and Isa (2008); Wan Yusof et. al. } \\
\text { (2008); Kumar et. al. (2009); Abuosi and Atinga (2013); Raajpoot (2004) }\end{array}$ \\
\hline Reliability & $\begin{array}{l}\text { Parasuraman et.al. (1985, 1988); Cronin and Taylor (1992); Kilbourne et. } \\
\text { al. (2004); Aguset. al. (2007); Amin and Isa (2008); Wan Yusof et. al. } \\
\text { (2008); Kumar et. al. (2009); Abdullah et. al. (2011); Abuosi and Atinga } \\
\text { (2013); Voonet. al. (2014); Raajpoot (2004) }\end{array}$ \\
\hline Responsiveness & $\begin{array}{l}\text { Parasuraman et.al. (1985, 1988); Cronin and Taylor (1992); Kilbourne et. } \\
\text { al. (2004); Aguset. al. (2007); Amin and Isa (2008); Wan Yusof et. al. } \\
\text { (2008); Kumar et. al. (2009); Abdullah et. al. (2011); Voon et. al. (2014) }\end{array}$ \\
\hline Assurance & $\begin{array}{l}\text { Parasuraman et.al. (1985, 1988); Cronin and Taylor (1992); Aguset. al. } \\
\text { (2007); Amin and Isa (2008); Wan Yusof et. al. (2008, 2010); Kumar et. al. } \\
\text { (2009); Raajpoot (2004) }\end{array}$ \\
\hline Empathy & $\begin{array}{l}\text { Parasuraman et.al. (1985, 1988); Cronin and Taylor (1992); Kilbourne et. } \\
\text { al. (2004); Aguset. al. (2007); Amin and Isa(2008); Wan Yusof et. al. } \\
\text { (2008); Kumar et. al. (2009) }\end{array}$ \\
\hline $\begin{array}{l}\text { Sustainability } \\
\text { (Economy, Social } \\
\text { and Environment) }\end{array}$ & $\begin{array}{l}\text { Enquist et. al. (2007); Carter \& Rogers (2008); Lepage (2009); Sloan, } \\
\text { 2010; Lehtinen (2012); Fernando (2012); Tajbakhsh and Hassini (2015) }\end{array}$ \\
\hline
\end{tabular}

This review reveals that a few researchers in previous studies (Cronin and Taylor, 1992; Kilbourne et. al., 2004; Aguset. al., 2007; Wan Yusof et. al., 2008; Abuosi and Atinga, 2013; and Voonet. al., 2014) have modified the original SERVQUAL model in order to accommodate their areas of research. During the early years, the modified SERVQUAL model was developed and being used in research on service industry as discussed and shown in Table 1. The authors are of the opinion that based on the literature reviews, another area that has a major impact on service quality are sustainability factors. Therefore, using the original SERVQUAL model developed by Parasuraman et. al. (1988), a modified SERVQUAL model will be used in this research with 'sustainability' as an additional dimension. The summary of scholars and service quality dimensions together with additional dimensions in previous research used in the proposed SUSSERV models are shown in Table 2. SUSSERVis a model with twenty eight items comprises twenty two items from the original SERVQUAL model. In addition, two 
items each (totaling six) from the sustainability dimension namely economy, environment and society. The SUSSERV model has been developed based on literature reviews and prior studies related to the subject of this research as shown in Figure 5.SUSSERV is able to empirically measure consumers' perception toward the service quality provided by water and sewerage service companies.

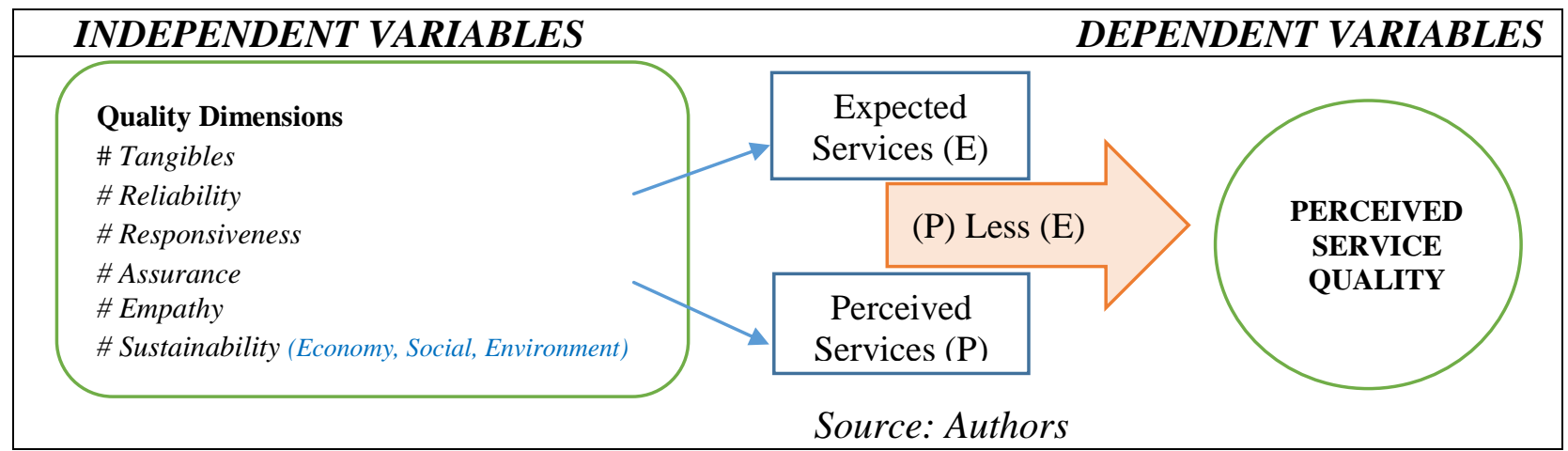

5.

Sum

mar

$\mathbf{y}$

and

Con

clusi

on

Figure 5: Conceptual Model - Sustainability Service Quality (SUSSERV)

Base

d on

the literature review, the authors' proposed SUSSERV model has achieved the research objective where it can be used to measure service quality and sustainability among the Malaysian Water Service companies. SUSSERV takes six components into consideration namely Tangible, Reliability, Responsiveness, Assurance, Empathy and Sustainability. The overall goal of this research, therefore, will be to implement the SUSSERV model to existing Malaysian water services industry. There is lack of research in service quality particularly in the context of Malaysian water services industry. Previous efforts and focus made on water quality and water treatment or process quality based were more technical in nature, thus this paper is an attempt to fill the gap between services, product and process quality by including sustainability.

\section{References}

Abdullah, F., Suhaimi, R., Saban, G. and Hamali, J. 2011. Bank Service Quality (BSQ) Index: An indicator of service performance. International Journal of Quality \& Reliability Management. 28(5): 542-555

Abratt, R. and Mofokeng, T.N. 2001. Development and management of corporate image in South Africa. European Journal of Marketing. Vol. 35(3/4): 368-386

Abuosi, A.A. and Atinga, R.A. 2013. Service quality in healthcare institutions: establishing the gaps for policy action. International Journal of Health Care Quality Assurance. 26(5): 481-492

Agus, A. and Hajinoor, M.S. 2012. Lean production supply chain management as driver towards enhancing products quality and business performance: case research of manufacturing companies in Malaysia. International Journal of Quality \& Reliability Management. 29(1): 92-121

Agus, A. Barker, S. and Kandampully, J. 2007. An exploratory research of service quality in the Malaysian public sector. International Journal of Quality \& Reliability Management. 24(2): 177190

Ali, A.J., Islam, M.A., and Howe L.P. 2013. A research of sustainability of continuous improvement in the manufacturing industries in Malaysia. Management of Environmental Quality: An International Journal. 24(3): 408-426

AmatTaap, M., Chong, S.C., Kumar, M. and Fong, T.K. 2011. Measuring service quality of conventional and Islamic bank: A comparative analysis. International Journal of Quality and Reliability Management. 28(8): 822-840

Amin, M. and Isa, Z. (2008). An examination of the relationship between service quality perception and 
customer satisfaction. A SEM approach towards Malaysian Islamic banking. International Journal of Islamic and Middle Eastern Finance and Management. 1(3): 191-209

Amran, A., Abdul Khalid, S.N., Abdul Razak, D. and Haron, H. 2010. Development of MBA with specialisation in sustainable development. International Journal of Sustainability in Higher Education. 11(3): 260-273

Carter, C.R. and Rogers, D.S. 2008. A framework of sustainable supply chain management: moving toward new theory. International Journal of Physical Distribution \& Logistics Management. 38(5): 360-387

Cronin, J.J. and Taylor, S.A. 1992. Measuring Service Quality: A re-examination and extension. Journal of Marketing. 56: 55-68

Cronin, J. J. 2003. Looking back to see forward in services marketing: some ideas to consider. Managing Service Quality: An International Journal. 13(5): 332-337

Enquist, B., Edvardsson, B. and Sebhatu, S.P. 2007. Value-based service quality for sustainable business. Managing Service Quality: An International Journal. 17(4): 385-403

Fatt, T.P.J, Wei, M., Yuen, S. and Suan, W. 2000. Enhancing corporate image in organisations. Management Research News. Vol. 23(5/6): 28-54

Fernando, R. (2012). Sustainable globalization and implications for strategic corporate and national sustainability. Corporate Governance: The international journal of business in society. 12(4): 579-589

Garvin, D.A. 1984. What Does "Product Quality" Really Mean?.Sloan Management Review. 25-43; http://sloanreview.mit.edu/article/

Gronroos, C. 1978. A Service-Orientated Approach to Marketing of Services. European Journal of Marketing. 12(8): 588-601

Gronroos, C. 1982. An Applied Service Marketing Theory. European Journal of Marketing. 16(7): 3041

Gronroos, C. 1984. A Service Quality Model and its Marketing Implications. European Journal of Marketing. 18(4): 36-44

Gronroos, C. 1988. New Competition in the Service Economy: The Five Rules of Service. International Journal of Operations \& Production Management. Vol. 8(3): 9-19

Gronroos, C. 1998. Marketing services: the case of a missing product. Journal of Business \& Industrial Marketing. 13(4/5): 322-338

Gronroos, C. 2001. The perceived service quality concept - a mistake?.Managing Service Quality: An International Journal. 11(3): 150-152

Gronroos, C. 2008. Service logic revisited: who creates value? And who co-creates?.European Business Review. 20(4): 298-314

Habiba, U., Abedin, A.M. and Shaw, R. 2014. Defining Water Insecurity InWater Insecurity: A Social Dilemma. Published online (Emerald Insight). 20 August 2014; 3-20

Hosseinpour, A., Peng, Q. and Gu, P. 2015. A benchmark-based method for sustainable product design. Benchmarking: An International Journal, 22(4): 643-664

Joseph, C. 2013. Understanding sustainable development concept in Malaysia. Social Responsibility Journal. 9(3): 441-453

Kang, G.D. and James, J. 2004. Service quality dimensions: an examination of Gronroos's service quality model. Managing Service Quality: An International Journal. 14(4): 266-277

Kheong, C.Y. 2008. The Water Tablet - Malaysian Water Reforms, Ministry of Energy, Water and Green Technology Malaysia: MPH Group Printing (M) Sdn. Bhd.

Kilbourne, W.E., Dufty,J.A., Duffy, M. and Giarchi, G. 2004. The applicability of SERVQUAL in cross-national measurement of health care quality. Journal of Services Marketing. 18(7): 524533

Kong, S.M. and Muthusamy, K. 2011. Using service gaps to classify quality attributes. The TQM 
Journal. 23(2): 145-163

Kumar, M., Kee, F.T. and AmatTaap, M. 2009. Determining the relative importance of critical factor in delivering service quality of banks. Managing Service Quality: An International Journal. 19(2): 211-228

Lam, S.Y., Lee, V.H., Ooi, K.B. and Phusavat, K. 2012. A structural equation model of TQM, market orientation and service quality: evidence from developing country. Managing Service Quality: An International Journal. 22(3): 281-309

Lehtinen, U. 2012. Sustainability and local food procurement: a case study of Finnish public catering. British Food Journal. 114(8): 1053-1071

Lepage, A. 2009. The quality of life as attribute of sustainability. The TQM Journal. 21(2): 105-115

Naik, C.N.K., Gantasala, S.B. and Prabhakar, G.V. 2010. Service Quality (Servqual) and its effect on Customers Satisfaction in Retailing. European Journal of Social Science. 16(2): 231-243

Parasuraman, A., Zeithaml, V.A. and Berry, L.L. 1985. A Conceptual Model of Service Quality and Its Implications for Future Research. The Journal of Marketing. 49(4): 41-50

Parasuraman, A., Zeithaml, V.A. and Berry, L.L. 1988. SERVQUAL: A Multiple-Item Scale for Measuring Consumer Perceptions of Service Quality. Journal of Retailing. 64(1): 12-40

Parasuraman, A. 1998. Customer service in business-to-business markets: an agenda for research. Journal of Business \& Industrial Marketing. 13(4/5): 309-321

Parasuraman, A. 2004. Assessing and improving service performance for maximum impact: insights from a two-decade-long research journey. Performance Measurement and Metrics. 5(2): 45-52

Parasuraman, A. 2010. Service productivity, quality and innovation: Implication for service-design practice and research. International Journal of Quality and Service Sciences. 2(3): 277-286

Raajpoot, N. 2004, "Reconceptualizing service encounter quality in non-western context", Journal of Service Research. 7(2): 181-201

Sloan, T.W. 2010. Measuring the Sustainability of Global Supply Chains: Current Practices and Future Directions. Journal of Global Business Management.: _

Tajbakhsh, A. and Hassini, E. 2015. Performance measurement of sustainable supply chains: a review and research questions. International Journal of Productivity and Performance Management. 64(6): 744-783

Voon, B.H., Lee, N. and Murray, D. 2014. Sports service quality for event venues: evidence from Malaysia. Sports, Business and Management: An International Journal. 4(2): 125-141

Wan Yusoff, W.Z., Ismail, M. and Newell, G. 2008. FM-SERVQUAL - a new approach of service quality measurement framework in local authorities. Journal of Corporate Real Estate. 10(2): 130-144

Yusof, S,M, and Aspinwall, E. 2001. Case studies on the implementation of TQM in the UK automotive SMEs. International Journal of Quality \& Reliability Management. 18(7): 722-744 